\title{
Meteorological and hydrodynamic data in the Mar Grande and Mar Piccolo, Italy, of the Coastal Engineering Laboratory (LIC) Survey, winter and summer 2015
}

\author{
Michele Mossa $^{1,2}$, Elvira Armenio ${ }^{3}$, Mouldi Ben Meftah ${ }^{1,2}$, Maria Francesca Bruno ${ }^{1,2}$, Diana De \\ Padova $^{1,2}$, and Francesca De Serio ${ }^{1,2}$ \\ ${ }^{1}$ Department of Civil, Environmental, Land, Building Engineering and Chemistry (DICATECh), \\ Polytechnic University of Bari, Via Orabona 4, 70125 Bari, Italy \\ ${ }^{2}$ Interuniversity Consortium for Marine Sciences (CoNISMa), Piazzale Flaminio 9, 00196 Rome, Italy \\ ${ }^{3}$ Regional Agency for Environmental Protection, ARPA Puglia, Corso Trieste 27, 70126 Bari, Italy
}

Correspondence: Diana De Padova (diana.depadova@poliba.it)

\author{
Received: 7 August 2020 - Discussion started: 1 October 2020 \\ Revised: 19 January 2021 - Accepted: 20 January 2021 - Published: 23 February 2021
}

\begin{abstract}
The Coastal Engineering Laboratory (LIC) of DICATECh of the Polytechnic University of Bari (Italy) maintains a place-based research programme in the Mar Grande and Mar Piccolo of Taranto (a coastal system in southern Italy), providing records of hydrodynamic and water-quality measurements. This site is one of the most complex marine ecosystem models in terms of ecological, social and economic activities. It is considered highly vulnerable because of the presence of a naval base, the biggest steel mill of Europe and an oil refinery. Two fixed stations have been installed, one in the Mar Grande (MG station) and another in Mar Piccolo (MP station). In the MG station constituents include wind speed and direction, air temperature and humidity, barometric pressure, net solar radiation, water salinity, water temperature, water pressure, dissolved oxygen, fluorescence, turbidity, CDOM, crude oil and refined fuels, sea currents, and waves. In the MP station constituents include water temperature, sea currents and waves. We provide a summary of how these data have been collected by the research group and how they can be used to deepen understanding of the hydrodynamic structures and characteristics of the basin.
\end{abstract}

These data are available at https://doi.org/10.5281/zenodo.4449641 (Mossa et al., 2020).

\section{Background and summary}

Coastal sites with typical lagoon features are extremely vulnerable, often suffering scarce circulation (de Swart and Zimmerman, 2009; De Pascalis et al., 2016; De Serio and Mossa, 2016a, b; Armenio et al., 2016, 2017a, b; De Padova et al., 2020; Carlucci et al., 2020). The two bays of the Mar Piccolo have been considered two different ecosystems influencing each other. The Mar Piccolo with its typical lagoon features is extremely vulnerable and is characterized by continual diffusion of contaminants with a strong ecological risk to the marine ecosystem and human health.

Especially in this case of shallow basins subjected to strong anthropization and urban discharges, it is fundamental to monitor the basins' hydrodynamics and water quality (De Carolis et al., 2013; De Serio and Mossa, 2014, 2015, 2016a, 2018; De Padova et al., 2017a, b; Armenio et al., 2018a, b, 2019; De Serio et al., 2020; Chimienti et al., 2020).

This monitoring action has proved to be a necessary tool for local authorities and stakeholders, allowing them to deepen their knowledge of the physical processes recurring in the target basin and to check these processes' real-time status. Moreover, it allows authorities and stakeholders to control sediment transport and effluent discharges, which are phenomena strictly linked to current magnitudes and directions (De Serio and Mossa, 2013, 2016c; Green and Coco, 2014; Ben Meftah et al., 2014, 2015, 2018; Mossa et al., 2017; Mossa, 2004). 


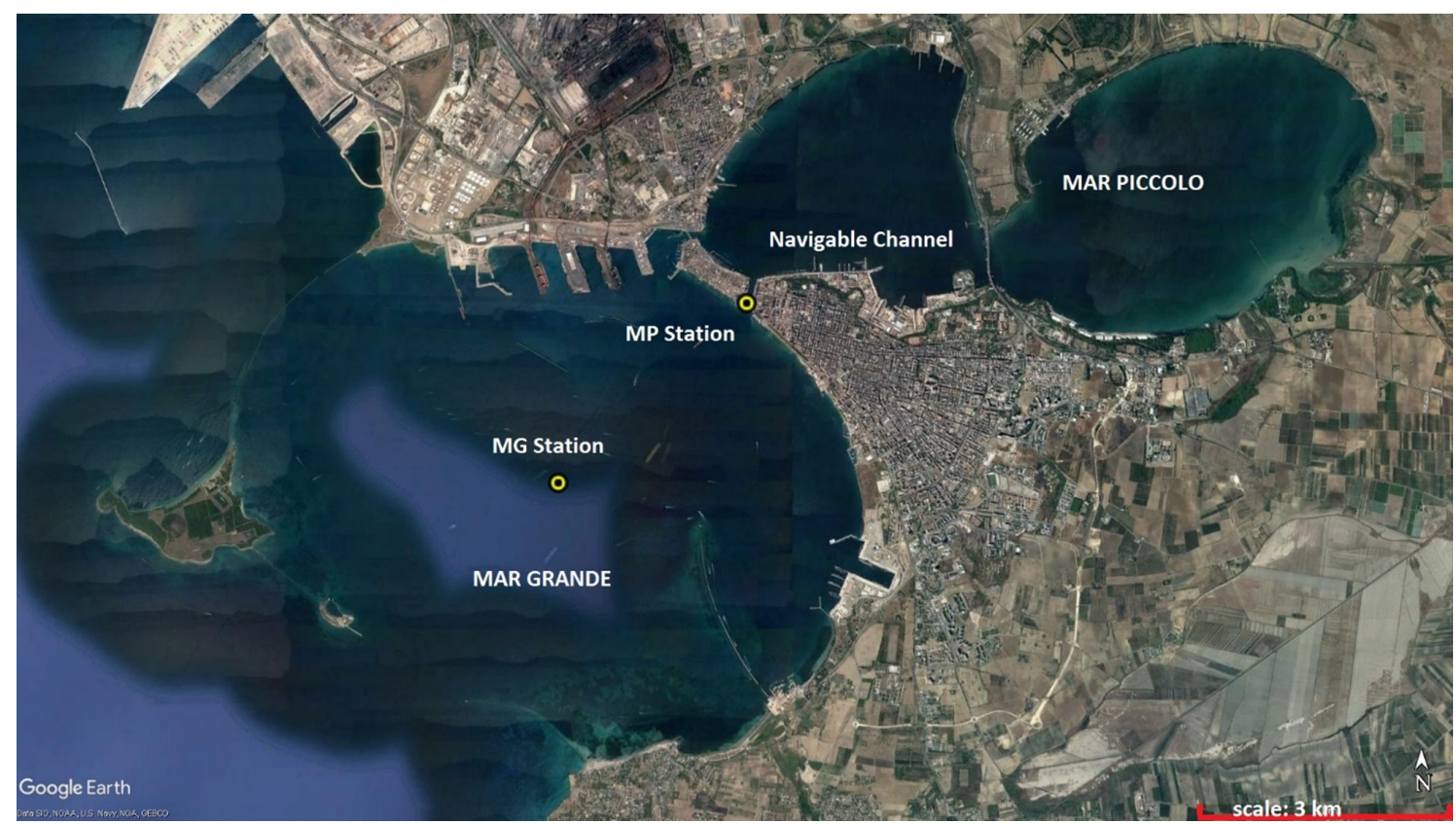

Figure 1. Map of the Mar Grande and Mar Piccolo coastal system, with the location of the two monitoring stations MG and MP. Source: Google Earth.

Table 1. Main characteristics of the two monitoring stations MG and MP.

\begin{tabular}{ll}
\hline Design type(s) & Time series design \\
\hline Measurement type(s) & $\begin{array}{l}\text { MG station: wind speed and di- } \\
\text { rection, air temperature and hu- } \\
\text { midity, barometric pressure, net } \\
\text { solar radiation, water salinity, } \\
\text { water temperature, water pres- } \\
\text { sure, dissolved oxygen, fluores- } \\
\text { cence, turbidity, CDOM, crude } \\
\text { oil and refined fuels, sea cur- } \\
\text { rents, and waves. MP station: } \\
\text { water temperature, sea currents } \\
\text { and waves } \\
\text { Data acquisition system } \\
\text { Technology type(s) } \\
\text { Factor type(s) }\end{array}$ Spatiotemporal interval \\
Sample characteristic(s) & Mar Grande and Mar Piccolo of \\
& Taranto, coastal waters \\
\hline
\end{tabular}

Therefore, coastal management plans and in situ decisionmaking should include such monitoring actions to guarantee thorough knowledge of hydrodynamic and tracer diffusion processes. Generally numerical models are preferred for this scope, because they allow us to reproduce and predict marine physical phenomena in a relatively short time, with accuracy and with moderate costs (De Serio et al., 2007, 2020; Monti and Leuzzi, 2010; Samaras et al., 2016; Di Bernardino et al., 2016). Predictive operational oceanography commonly uses models covering regional, sub-regional

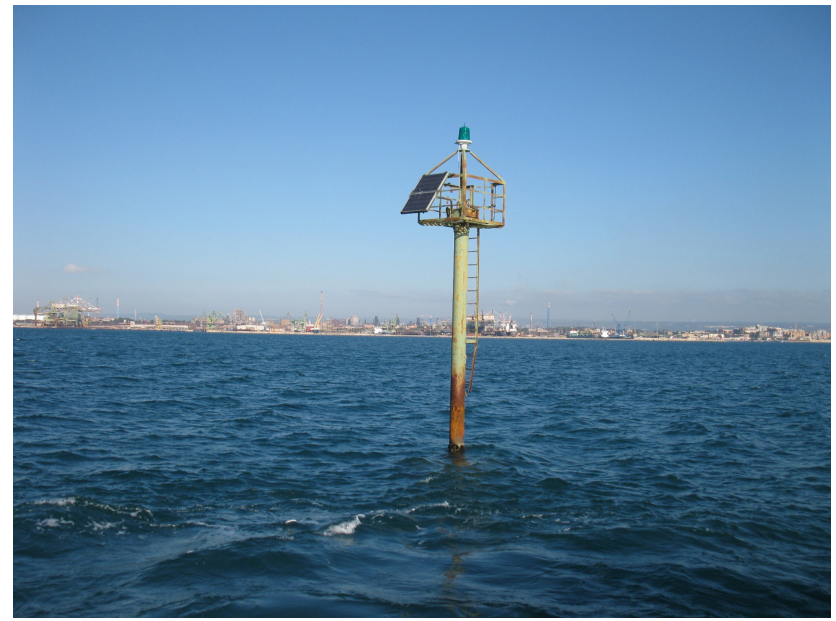

Figure 2. Seamark where the monitoring station in the Mar Grande was installed.

and shelf-coastal scales. To study local scales, with a resolution of a few hundred metres, multiscale modelling systems based on a multiple-nesting approach have lately been implemented (Lane et al., 2009; Federico et al., 2017). Therefore, a large dataset is essential to calibrate and validate modelling systems providing forecasts (Lesser et al., 2004; Korotenko et al., 2010; Sánchez-Arcilla et al., 2014).

At the same time, a large dataset allows us to deduce information on the evolutionary state of the analysed basin. The present note aims to show how long-term and continuous recordings of meteorological, hydrodynamic and water- 

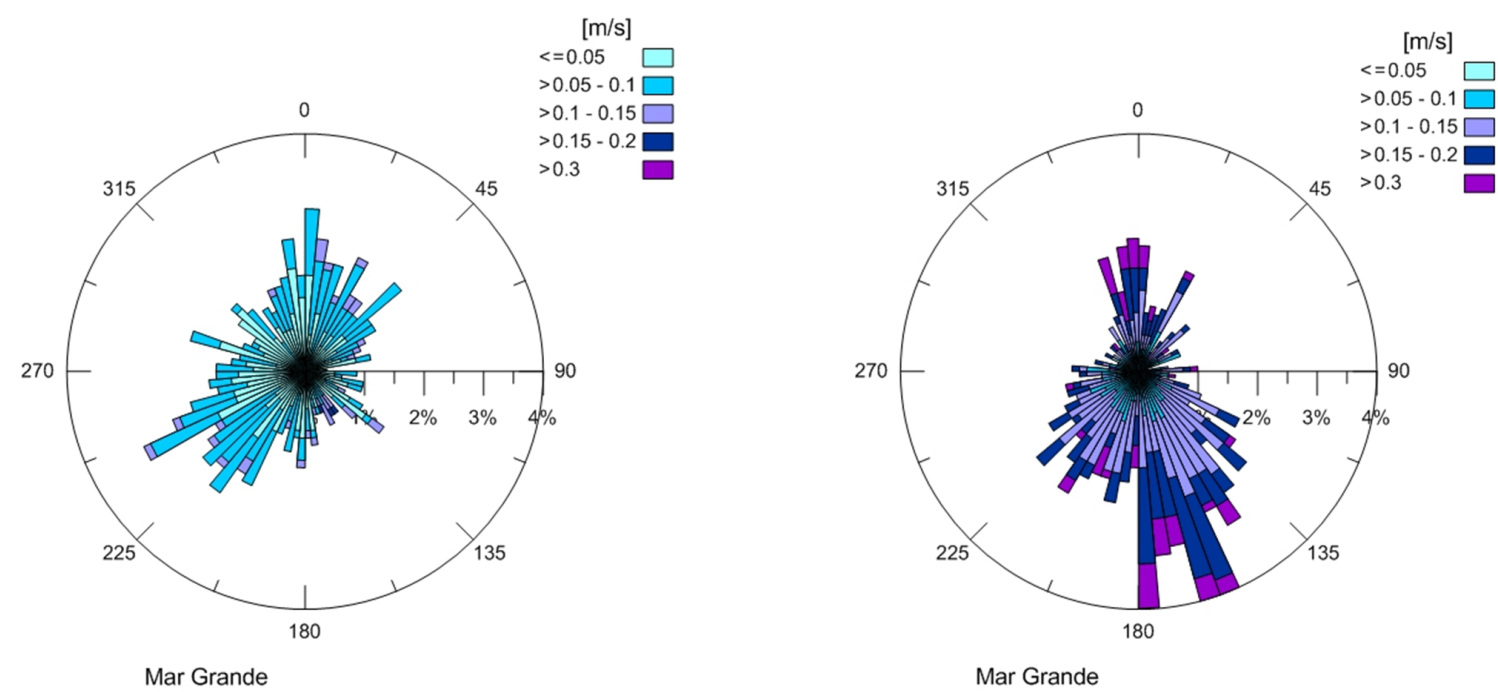

Bottom currents - January 2015

Mar Grande

Surface currents - January 2015

Figure 3. Polar plot of measured bottom and surface currents in January 2015 (direction of propagation shown).

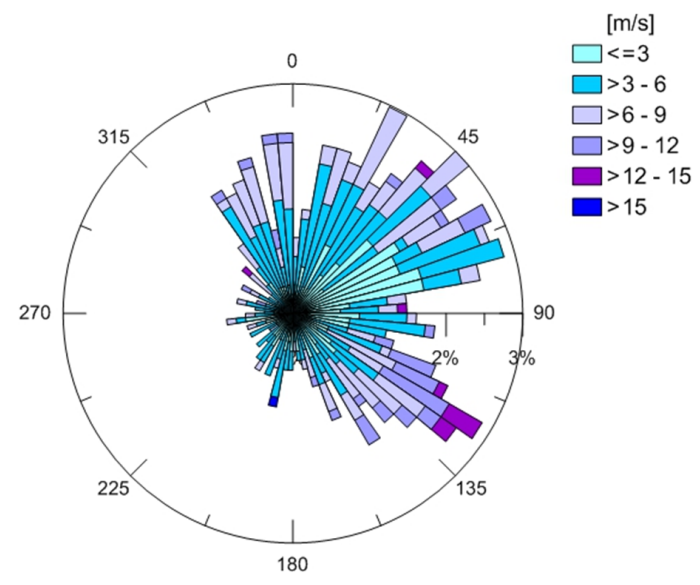

Mar Grande

wind - January 2015

incoming direction

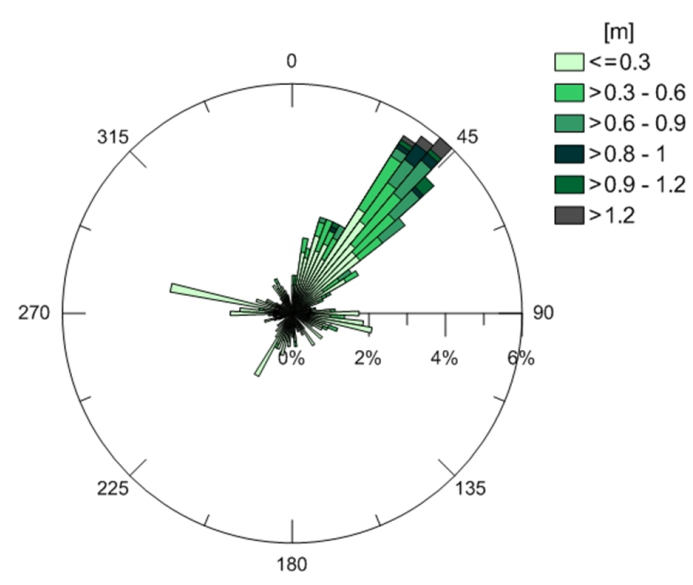

Mar Grande

waves - January 2015

direction of propagation

Figure 4. Polar plot of measured wind and waves in January 2015.

quality data collected in a semi-enclosed sea can be managed to rapidly provide fundamental insights into its hydrodynamic structure and environmental health. The acquired signals have been analysed in both time and frequency domains, filtered and grouped into classes with homogeneous features, and then correlated. This simple and repeatable procedure has been applied with good results (De Serio and Mossa, 2015, 2016a; Armenio et al., 2017a, b), which are interesting from a predictive perspective and for numerical modelling (Kjerfve and Magill, 1989; Babu et al., 2005; Ferrarin et al., 2008; De Serio and Mossa, 2016c; Benetazzo et al., 2012). Although the typical trends in the water circulation and exchanges have been studied by numerous models developed for the seas of Taranto, more observations, monitoring actions and numerical modelling are still necessary to better understand the most significant hydrodynamic-biological variability in this coastal basin. The results of this study can be applied to similar zones.

\section{Method and sampling}

The hydrodynamic and water-quality studies in the Mar Grande and Mar Piccolo of Taranto (Fig. 1) of the LIC (Coastal Engineering Laboratory of DICATECh of the Polytechnic University of Bari) include two fixed stations briefly described below. 
Table 2. Dataset of the two monitoring stations MG and MP.

\begin{tabular}{|c|c|c|}
\hline & & Mar Piccolo (MP) \\
\hline & & $\mathrm{x}$ \\
\hline \multirow[t]{2}{*}{ Wave } & $\begin{array}{l}\text { Progressive data number, } \\
\text { date (year, month, day, hour, } \\
\text { minute), position (lat, long) }\end{array}$ & $\begin{array}{l}\text { - SDN:P01::GTHDAP01 - significant wave height } H_{\mathrm{S}}(\mathrm{m}) \\
\text { - SDN:P01::GTZHAW01 - significant wave period } T_{\mathrm{S}}(\mathrm{s}) \\
\text { - SDN:P01::GWMDAD01 - significant wave incoming direction (in } \\
\text { degrees, referenced to the north) } \\
\text { - SDN:P01::MBANZZZZ - local depth (mm) } \\
\text { - SDN:P01::GTDHAP01 - } H_{1 / 10} \text {, average of the highest } 1 / 10 \text { of waves } \\
\text { - SDN:P01::GTAMZD01 - average wave period } T_{\text {mean }}(\mathrm{s})\end{array}$ \\
\hline & & $\mathrm{x}$ \\
\hline \multirow[t]{2}{*}{ Current } & $\begin{array}{l}\text { Progressive data number, } \\
\text { date (year, month, day, hour, } \\
\text { minute), position (lat, long) }\end{array}$ & $\begin{array}{l}\text { - SDN:P01::MBANZZZZ - cell of measurement with indication of its } \\
\text { depth from surface }(z=0) \\
\text { - SDN:P01::LCSAAP01 - cell current intensity }\left(\mathrm{m} \mathrm{s}^{-1}\right) \\
\text { - SDN:P01::LCDAAP01 - cell current direction (in degrees, referenced to } \\
\text { the north) }\end{array}$ \\
\hline & & $\mathrm{x}$ \\
\hline \multirow[t]{2}{*}{ Temperature } & $\begin{array}{l}\text { Progressive data number, } \\
\text { date (year, month, day, hour, } \\
\text { minute), position (lat, long) }\end{array}$ & $\begin{array}{l}\text { - SDN:P01::MBANZZZZ - sensor depth }(\mathrm{m}) \\
\text { - SDN:P01::TEMPS901 - water potential temperature measured in ITS-90 } \\
\text { degrees Celsius }\left({ }^{\circ} \mathrm{C}\right)\end{array}$ \\
\hline & & 皮 \\
\hline \multirow[t]{2}{*}{ Meteorological } & $\begin{array}{l}\text { Progressive data number, } \\
\text { date (year, month, day, hour, } \\
\text { minute), position (lat, long) }\end{array}$ & $\begin{array}{l}\text { - SDN:P01::EGTSSS01 - average wind velocity }\left(\mathrm{m} \mathrm{s}^{-1}\right) \\
\text { - SDN:P01::ESSAMX01 - max wind velocity }\left(\mathrm{m} \mathrm{s}^{-1}\right) \\
\text { - SDN:P01::EGTDSS01 - wind incoming direction N }(\mathrm{deg}) \\
\text { - SDN:P01::CDTAZZ01 - air temperature }\left({ }^{\circ} \mathrm{C}\right) \\
\text { - SDN:P01::CDEWZZ01 - dew point }\left({ }^{\circ} \mathrm{C}\right) \\
\text { - SDN:P01::CAPHZZ01 - atmospheric pressure (mbar) } \\
\text { - SDN:P01::CHUMZZ01 - relative humidity }(\%)\end{array}$ \\
\hline & & $\mathrm{x}$ \\
\hline Water quality & $\begin{array}{l}\text { Progressive data number, } \\
\text { date (year, month, day, hour, } \\
\text { minute), position (lat, long) }\end{array}$ & $\begin{array}{l}\text { - SDN:P01::TEMPS901 - water potential temperature measured in ITS-90 } \\
\text { degrees Celsius }\left({ }^{\circ} \mathrm{C}\right) \\
\text { - SDN:P01::CNDCST01 - conductivity }\left(\mathrm{S} \mathrm{m}^{-1}\right) \\
\text { - SDN:P01::PRESPR01 - absolute pressure (dbar) } \\
\text { - SDN:P01::PSLTZZ01 - practical salinity (PSU) using PSS-78 algorithm } \\
\text { - SDN:P01::SIGTPR01 - density }\left(\mathrm{kg} \mathrm{m}^{-3}\right) \\
\text { - SDN:P01::DOXYOP01 - dissolved oxygen }\left(\mathrm{mLL}^{-1}\right) \\
\text { - SDN:P01::CLSDPM01 - chlorophyll }\left(\mu \mathrm{L}^{-1}\right) \\
\text { - SDN:P01::CLSDPM01 - turbidity (NTU) } \\
\text { - SDN:P01::GP001 - CDOM (RFU) } \\
\text { - SDN:P01::GP001 - crude oil (RFU) } \\
\text { - SDN:P01::GP001 - refined oil (RFU) }\end{array}$ \\
\hline
\end{tabular}


In December 2013, the first meteo-oceanographic station MG was mounted in the Mar Grande basin, at the geographical coordinates $40^{\circ} 27.6^{\prime} \mathrm{N}, 17^{\circ} 12.9^{\prime} \mathrm{E}$ (Figs. 1 and 2 ). It was funded by the Italian national project PON R\&C 2007-2013 "Magna Grecia" and the RITMARE Flagship Project (Italian Research for the Sea, where we operated as the research unit CoNISMa-Polytechnic University of Bari) provided by the Italian Ministry of Education, University and Research (De Serio and Mossa, 2016a, b; Armenio et al., 2017). The local depth at this station is on average equal to $23.25 \mathrm{~m}$. At this station a bottom-mounted acoustic Doppler current profiler (ADCP), a multidirectional wave array, a weather station and a CTD (Sea-Bird SBE 37-SIP-ODO with sensors of conductivity, temperature, pressure and dissolved oxygen) were installed (Fig. 2).

Further, sensors by Wet Labs and Turner Designs to detect water physical and biochemical parameters completed the station. The water parameters were measured on average at a depth equal to $5.6 \mathrm{~m}$ below the sea surface.

In detail, the weather system by MetPak was installed on the seamark where the monitoring MG station is present. It records speed and wind direction by means of an ultrasonic sensor. Hourly averaged values of wind speed and direction are provided with an accuracy of $\pm 2 \%$ of the velocity value and $\pm 3^{\circ}$ of the direction.

The ADCP (by Teledyne RD Instruments) measured the $3 \mathrm{D}$ velocity of currents along the vertical. It uses a Janus configuration consisting of four acoustic beams, paired in orthogonal planes, where each beam is inclined at a fixed angle of $20^{\circ}$ to the vertical. The ADCP is bottom mounted and upward facing and has a pressure sensor for measuring mean water depth. The transducer head is at $0.50 \mathrm{~m}$ above the seafloor. Velocities are sampled along the water column with a $0.50 \mathrm{~m}$ vertical bin resolution and a $1.60 \mathrm{~m}$ blanking distance. Therefore, the water column is investigated from a distance from the sea bottom of $z=2.1 \mathrm{~m}$ up to the most superficial bin not biased by waves. The surface layer, with a thickness on average equal to $2.0 \mathrm{~m}$, is excluded from the analysis, to filter out possible noise in the measurements as well as the wave contribution to currents. Mean current velocity profiles are collected continuously at $1 \mathrm{~h}$ intervals, using an average of 60 measurements acquired every $10 \mathrm{~s}$. In this way, hourly averaged velocity components along the water column are available (De Serio and Mossa, 2016a, b; Armenio et al., 2017). Figure 3 shows an example of polar plots of the measured bottom and surface currents in January 2015.

In May 2014, funded by the Flagship Project RITMARE, the station MP was also placed in the target area. Namely it was installed in the navigable channel, at the geographical coordinates $40^{\circ} 28.38^{\prime} \mathrm{N}, 17^{\circ} 14.08^{\prime} \mathrm{E}$, because it is the main exchange between the Mar Piccolo and Mar Grande (Fig. 1). As shown by previous studies and field data analysis from MP station (Armenio et al., 2017a; De Serio and Mossa, 2018; De Serio et al., 2020), the net flow is inflowing at deeper layers, from the bottom up to a $4 \mathrm{~m}$ depth, while in the most superficial layer it is directed outward from the basin. Therefore, monitoring actions, such as that of MP station, are necessary to better understand the most significant hydrodynamic-biological variability in this extremely vulnerable coastal site.

The station is equipped with a bottom-mounted ADCP and a wave array (by Teledyne RD Instruments). The local depth at this station is on average equal to $13.7 \mathrm{~m}$. Also in this case, considering the ADCP size and its blanking distance, the current velocities are assessed along the vertical starting from $z=2.1 \mathrm{~m}$ from the seabed, at constant intervals of $0.5 \mathrm{~m}$, and up to the most detectable unbiased bin at $z=12.6 \mathrm{~m}$. The acoustic frequency of both the installed ADCPs is $600 \mathrm{kHz}$, and their velocity accuracy is $0.3 \%$ of the water velocity $\pm 0.003 \mathrm{~m} \mathrm{~s}^{-1}$.

In both MG and MP stations, the ADCP measures the component of velocity projected along the beam axis, averaged over a range cell. The cross spectra between velocities measured at various range cells (either beam to beam or along each beam) contain information about the wave direction (Armenio et al., 2017a). In other words, each depth cell of the ADCP can be considered an independent sensor that makes a measurement of one component of the wave field velocity. The ensemble of depth cells along the four beams constitutes an array of sensors from which magnitude and directional information about the wave field can be determined.

\section{Data record}

The dataset supplied in tab-delimited text format ASCII contains time series of relevant metocean variables marked up with the SeaDataNet common vocabularies from libraries P01, P02 and P03 (https://vocab.seadatanet.org/search, last access: 19 February 2021, vocabularies P01, P02, P03) and divided as shown in Table 2.

The dataset has been processed with quality control procedures and data flagged following SeaDataNet protocols.

In particular, the dataset quality control has been carried out with the following steps:

- maintenance and calibration of instruments twice a year in specialized laboratories,

- visual inspection of the time series (e.g. time series plot, current vector scatter plot, progressive vector diagram),

- screening together of related parameters such as current speed and current direction or salinity and temperature to identify spurious values,

- flagging of spikes in the data,

- flagging of suspicious data or correcting the data after consultation with the data supplier,

- checking against other data collected on nearby moorings or measured during monitoring survey using 


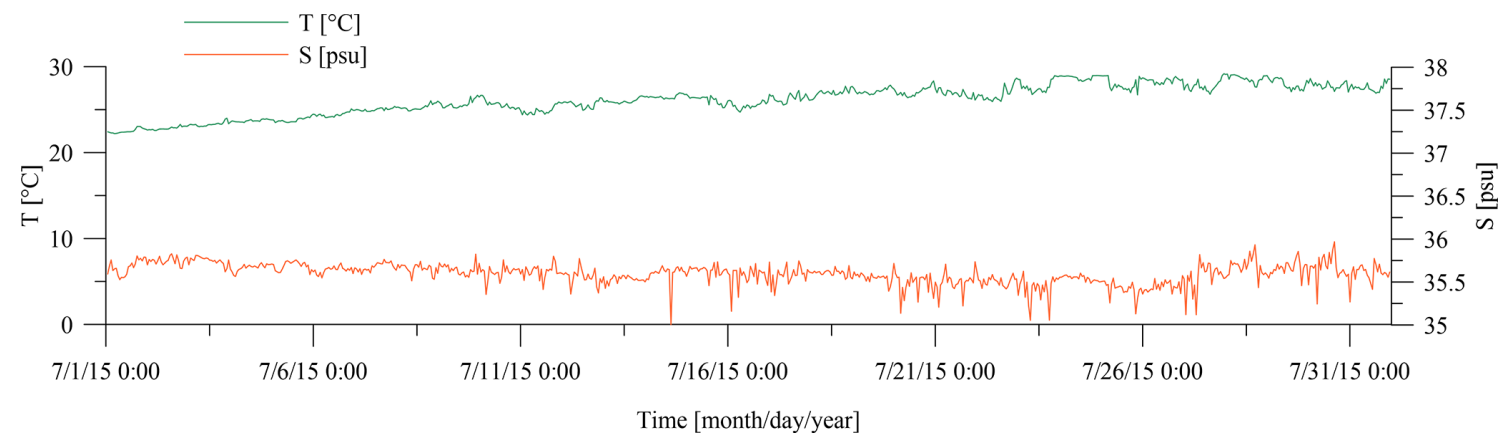

Figure 5. Time series of measured water temperature $\left[{ }^{\circ} \mathrm{C}\right]$ and salinity $[\mathrm{psu}]$ in July 2015 . Time is local time.

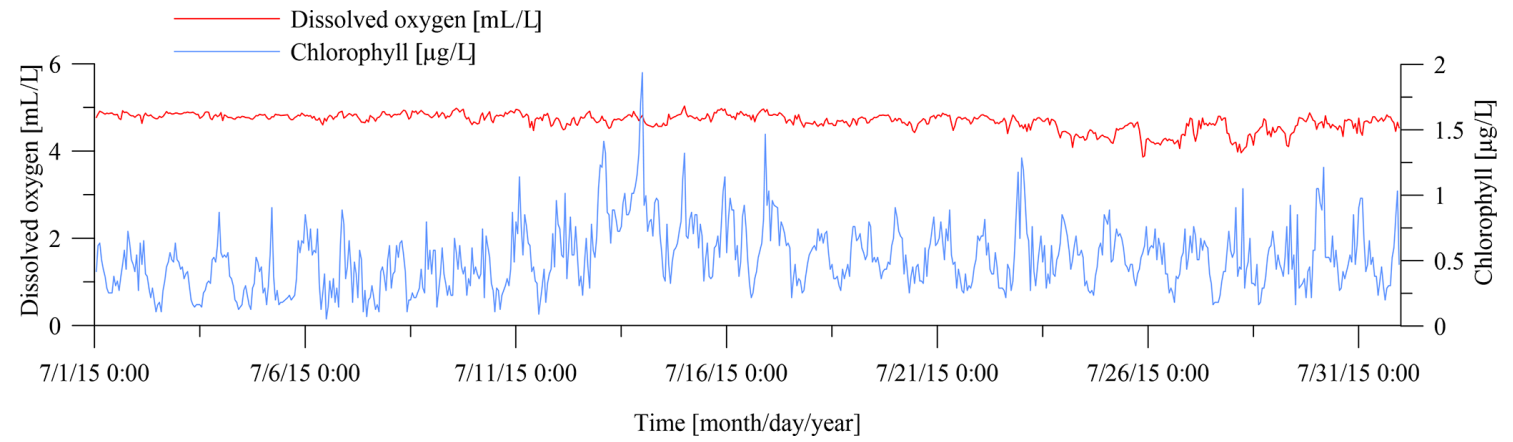

Figure 6. Time series of measured dissolved oxygen $\left[\mathrm{mLL}^{-1}\right]$ and chlorophyll $\left[\mu \mathrm{gL}^{-1}\right]$ in July 2015. Time is local time.

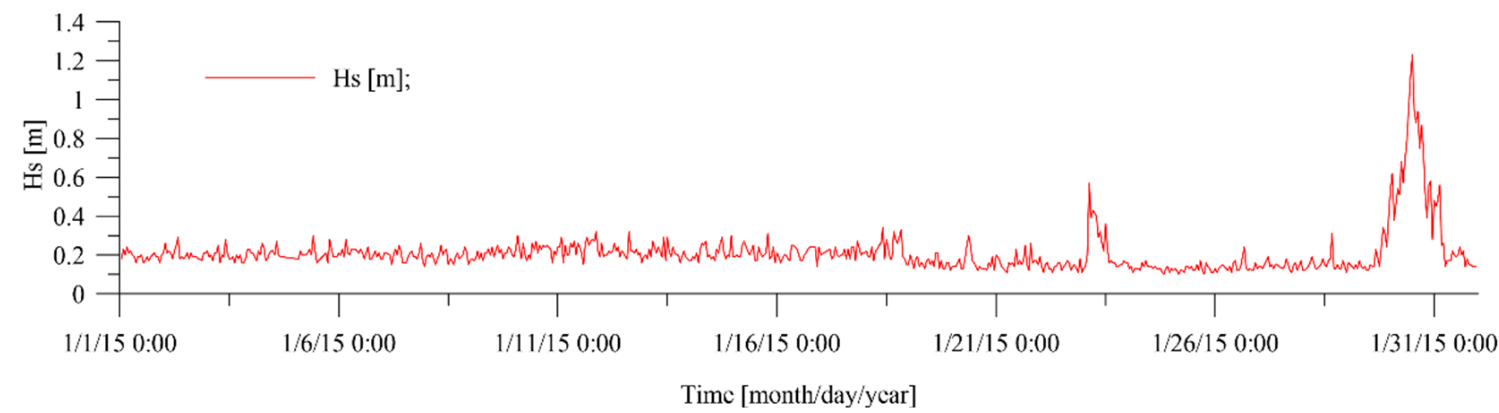

(a)

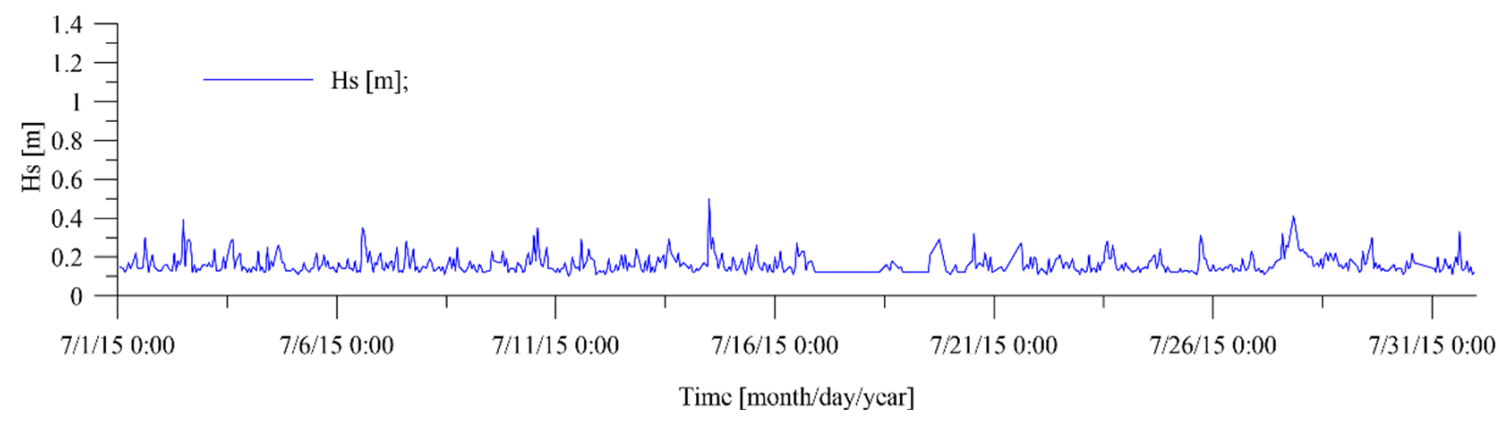

(b)

Figure 7. Time series of measured significant wave heights $H_{\mathrm{S}}$ recorded in (a) January 2015 and (b) July 2015. Time is local time. 
two vessel-mounted acoustic Doppler current profilers (VM-ADCPs).

\section{Data availability}

All data used in this paper are available at https://doi.org/10.5281/zenodo.4449641 (Mossa et al., 2020).

\section{Technical and data validation}

Results from all sampling data were examined carefully by the research team of the LIC to ensure that all values fell within expected ranges, to verify that calibration regressions were an acceptable basis for computing quantities from sensor measurements and to ensure completeness of each monthly acquisition.

When data were bad acquisitions or were lacking, they were eliminated from the file record.

Each dataset was validated with (1) tests to ensure that the measured values fell within ranges that are plausible and consistent with knowledge of the Mar Piccolo and Mar Grande systems and (2) pattern tests of time series of all measurements to ensure they followed plausible and understandable patterns of variability over time (Babu et al., 2005; Ferrarin et al., 2008).

As also shown in previous works (De Serio and Mossa, 2016a, b; Armenio et al., 2017), examples of plots deduced by the dataset are displayed for MG station (Figs. 3-6) and MP station (Fig. 7).

Figure 3 shows the pattern of the bottom and surface currents typical of the January month. The prevalence of currents directed towards the SW confirms the deductions of other experimental works, proving that the site topography controls bed circulation and induces a bottom current outflowing from the SW opening in the Mar Grande border (De Serio and Mossa, 2016a, b; Armenio et al., 2017) which is also in accordance with results of numerical models (De Pascalis et al., 2016).

On the contrary, the significant waves enter from the same opening and spread throughout the basin and are thus not influenced by prevailing winds (Fig. 4). Therefore, this SW opening represents a dominant key factor in the hydrodynamics of the basin.

Figure 5 displays the water temperature trend in the July month, which increases as expected, and the salinity trend, which seems consistent with increasing evaporation rates and reduced riverine inputs. In Fig. 6 the time series of dissolved oxygen and chlorophyll are plotted, with peaks due to the algal bloom of the period.

Figure $7 \mathrm{a}$ and $\mathrm{b}$ show the time series of the significant wave heights recorded in January 2015 and July 2015, respectively. In the January month, the greatest value of observed $H_{\mathrm{s}}$ is equal to $1.2 \mathrm{~m}$ and the average value of $H_{\mathrm{s}}$ is around $0.2 \mathrm{~m}$. In the July month, the greatest value of observed $H_{\mathrm{s}}$ is equal to $0.5 \mathrm{~m}$ and the average value of $H_{\mathrm{s}}$ is around $0.15 \mathrm{~m}$.

Author contributions. MM, EA, MBM, DDP, MFB and FDS managed the survey programme. MM, DDP and FDS processed and organized the datasets and wrote the paper. MM conceived and coordinated the activities.

Competing interests. The authors declare no competing financial interests.

Acknowledgements. The authors thank the Research Unit of the CoNISMa of the University of Bari "Aldo Moro" and the technicians who conducted the installation and maintenance of the stations.

Financial support. The monitoring stations were settled in the frame of the Italian Flagship Project RITMARE and with funds from PON R\&C 2007-13 Project (chief scientist of both Michele Mossa). The present work was partially funded by an agreement between the Polytechnic University of Bari and the Special Commissioner for urgent measures of reclamation, environmental improvements and redevelopment of Taranto.

Review statement. This paper was edited by Giuseppe M. R. Manzella and reviewed by Stefano Sibilla and Athanasia Iona.

\section{References}

Armenio, E., Ben Meftah, M., Bruno, M. F., De Padova, D., De Pascalis, F., De Serio, F., Di Bernardino, A., Mossa, M., Leuzzi, G., and Monti, P.: Semi enclosed basin monitoring and analysis of meteo, wave, tide and current data, in: Proceedings of the IEEE Conference on Environmental, Energy and Structural Monitoring Systems, Bari, Italy, ISBN 978-1-5090-2369-1, 9781-5090-2370-7, https://doi.org/10.1109/EESMS.2016.7504835, 13-14 June 2016.

Armenio, E., De Serio, F., and Mossa, M.: Analysis of data characterizing tide and current fluxes in coastal basins, Hydrol. Earth Syst. Sci., 21, 3441-3454, https://doi.org/10.5194/hess-21-34412017, 2017a.

Armenio, E., De Padova, D., De Serio, F., and Mossa, M.: Monitoring system for the sea: Analysis of meteo, wave and current data, IMEKO TC19 Workshop on Metrology for the Sea, MetroSea 2017: Learning to Measure Sea Health Parameters, October 2017, 143-148, 2017b.

Armenio, E., De Serio, F., and Mossa, M.: Environmental technologies to safeguard coastal heritage, SCIRES-IT, vol. 8, 61-78, ISSN: 2239-4303, https://doi.org/10.2423/i22394303v8n1p61, 2018a. 
Armenio, E., De Padova, D., De Serio, F., and Mossa, M.: Monitoring System in Mar Grande Basin (Ionian Sea), IEEE International Workshop on Metrology for the Sea, Learning to Measure Sea Health Parameters, https://doi.org/10.1109/MetroSea.2018.8657891, 2018b.

Armenio, E., Ben Meftah, M., De Padova, D., De Serio, F., and Mossa, M.: Monitoring systems and numerical models to study coastal sites, Sensors, 19, 1552, https://doi.org/10.3390/s19071552, 2019.

Babu, M. T., Vethamony, P., and Desa, E.: Modelling tidedriven currents and residual eddies in the Gulf of Kachchh and their seasonal variability: A marine environmental planning perspective, Ecol. Model., 184, 299-312, 2005.

Ben Meftah, M., De Serio, F., and Mossa, M.: Hydrodynamic behavior in the outer shear layer of partly obstructed open channels, Phys. Fluids, 26, 065102, https://doi.org/10.1063/1.4881425, 2014.

Ben Meftah, M., De Serio, F., Malcangio, D., Mossa, M., and Petrillo, A. F.: Experimental study of a vertical jet in a vegetated crossflow, J. Environ. Manag., 164, 19-31, 2015.

Ben Meftah, M., Malcangio, D., De Serio, F., and Mossa M.: Vertical dense jet in flowing current, Environ. Fluid Mech., 18, 75-96, https://doi.org/10.1007/s10652-017-9515-2, 2018.

Benetazzo, A., Carniel, S., Sclavo, M., and Bergamasco, A.: Wavecurrent interaction: Effect on the wave field in a semienclosed basin, Ocean Model. (Oxf), 70, 152-165, 2012.

Carlucci, R., Cipriano, G., Santacesaria, F.C., Ricci, P., Maglietta, R., Petrella, A., Mazzariol, S., De Padova, D., Mossa, M., Bellomo, S., and Fanizza, C.: Exploring data from an individual stranding of a Cuvier's beaked whale in the Gulf of Taranto (Northern Ionian Sea, Central-eastern Mediterranean Sea), J. Exp. Mar. Biol. Ecol., 533, 151473, 2020.

Chimienti, G., De Padova, D., Mossa, M., and Mastrototaro, F.: A mesophotic black coral forest in the Adriatic Sea, Sci. Rep., 10, 8504, https://doi.org/10.1038/s41598-020-65266-9, 2020.

De Carolis, G., Adamo, M., Pasquariello, G., De Padova, D., and Mossa, M.: Quantitative characterization of marine oil slick by satellite near-infrared imagery and oil drift modelling: the Fun Shai Hai case study, Int. J. Remote Sens., 34, 1838-1854, 2013.

De Padova, D., Mossa, M., Adamo, M., De Carolis, G., and Pasquariello, G.: Synergistic use of an oil drift model and remote sensing observations for oil spill monitoring, Environ. Sci. Pollut. Res. Int., 24, 5530-5543, 2017a.

De Padova, D., De Serio, F., Mossa, M., and Armenio, E.: Investigation of the current circulation offshore Taranto by using field measurements and numerical model, in: Proceedings of the 2017 IEEE International Instrumentation and Measurement Technology Conference (I2MTC), Turin, Italy, 22-25 May 2017, 2017 b.

De Padova, D., Ben Meftah, M., De Serio, F., and Mossa, M.: Management of Dredging Activities in a Highly Vulnerable Site: Simulation Modelling and Monitoring Activity, J. Mar. Sci. Eng., 8, 1020, https://doi.org/10.3390/jmse8121020, 2020.

De Pascalis, F., Petrizzo, A., Ghezzo, M., Lorenzetti, G., Manfè, G., Alabiso, G., and Zaggia, L.: Estuarine circulation in the Taranto Seas, J. Env. Sci. Pollut. Res., 23, 12515-12534, 2016.

De Serio, F. and Mossa, M.: A laboratory study of irregular shoaling waves, Exp. Fluids, 54, 1536, https://doi.org/10.1007/s00348013-1536-0, 2013.
De Serio, F. and Mossa, M.: Streamwise velocity profiles in coastal currents, Environ. Fluid Mech., 14, 895-918, 2014.

De Serio, F. and Mossa, M.: Analysis of mean velocity and turbulence measurements with ADCPs, J. Adv. Water Res., 81, 172$185,2015$.

De Serio, F. and Mossa, M.: Assessment of hydrodynamics, biochemical parameters and eddy diffusivity in a semi-enclosed Ionian basin, Deep-Sea Res. Pt II, 133, 176-185, 2016 a.

De Serio, F. and Mossa, M.: Environmental monitoring in the Mar Grande basin (Ionian Sea, Southern Italy), J. Environ. Sci. Pollut. Res., 23, 12662-12674, 2016 b.

De Serio, F. and Mossa, M.: Assessment of classical and approximated models estimating regular waves kinematics, Ocean Eng., 126, 176-186, 2016c.

De Serio, F. and Mossa, M.: Meteo and hydrodynamic measurements to detect physical processes in confined shallow seas, Sensors, 18, 280, https://doi.org/10.3390/s18010280, 2018.

De Serio, F., Malcangio, D., and Mossa, M.: Circulation in a Southern Italy coastal basin: Modelling and field measurements, Cont. Shelf Res., 27, 779-797, 2007.

De Serio, F, Armenio, E., Ben Meftah, M., Capasso, G., Corbelli, V., De Padova, D., De Pascalis, F., Di Bernardino, A., Leuzzi, G., Monti, P., Pini, A., Velardo, R., and Mossa, M.: Detecting sensitive areas in confined shallow basins, Eviron. Modell. Softw., 126, 1364-8152, https://doi.org/10.1016/j.envsoft.2020.104659, 2020.

De Swart, H. E. and Zimmerman, J. T. F.: Morphodynamics of tidal inlet systems, Annu. Rev. Fluid Mech., 41, 203-229, 2009.

Di Bernardino, A., De Serio, F., Mossa, M., Pini, A., Leuzzi, G., and Monti, P.: Micrometeorological simulations over coastal area using CALMET data, Proc. IEEE EESMS, 180-185, 2016.

Federico, I., Pinardi, N., Coppini, G., Oddo, P., Lecci, R., and Mossa, M.: Coastal ocean forecasting with an unstructured grid model in the southern Adriatic and northern Ionian seas, Nat. Hazards Earth Syst. Sci., 17, 45-59, https://doi.org/10.5194/nhess-17-45-2017, 2017.

Ferrarin, C., Umgiesser, G., Cucco, A., Hsu, T. W., Roland, A., and Amos, C. L.: Development and validation of a finite element morphological model for shallow water basins, Coast. Eng., 55, 716-731, 2008.

Green, M. O. and Coco, G.: Review of wave-driven sediment resuspension and transport in estuaries, Rev. Geophys., 52, 77-117, 2014.

Kjerfve, B. and Magill, K. E.: Geographic and hydrodynamic characteristics of shallow coastal lagoons, Mar. Geol., 88, 187-199, 1989.

Korotenko, K. A., Bowman, M. J., and Dietrich, D. E.: High resolution numerical model for predicting the transport and dispersal of oil spilled in the Black Sea, Terr. Atmos. Ocean Sci., 21, 123136, 2010.

Lane, E., Walters, R., Gillibrand, P., and Uddstrom, M.: Operational forecasting of sea level height using an unstructured grid ocean model, Ocean Modell., 28, 88-96, 2009.

Lesser, G. R., Roelvink, J. A., van Kester, J. A. T. M., and Stelling, G. S.: Development and validation of a three-dimensional morphological model, Coast. Eng., 51, 883-915, 2004.

Monti, P. and Leuzzi, G.: Lagrangian models of dispersion in marine environment, Env. Fluid Mech., 10, 637-656, 2010. 
Mossa, M.: Behavior of nonbuoyant jets in a wave environment, J. Hydraul. Eng., 130, 704-717, 2004.

Mossa, M., Ben Meftah, M., De Serio, F., and Nepf, H. M.: How vegetation in flows modifies the turbulent mixing and spreading of jets, Sci. Rep., 7, 6587, https://doi.org/10.1038/s41598-01705881-1, 2017.

Mossa, M., Armenio, E., Ben, M. M., Bruno, M. F., De Padova, D., and De Serio, F.: Meteo and hydrodynamic data in the Mar Grande and Mar Piccolo by the LIC Survey, winter and summer 2015 [Data set], Zenodo, https://doi.org/10.5281/zenodo.4449641, 2020.
Samaras, A. G., Gaeta, M. G., Miquel, A. M., and Archetti, R.: High-resolution wave and hydrodynamics modelling in coastal areas: operational applications for coastal planning, decision support and assessment, Nat. Hazards Earth Syst. Sci., 16, 14991518, https://doi.org/10.5194/nhess-16-1499-2016, 2016.

Sánchez-Arcilla, A., Wolf, J., and Monbaliu, J.: Oceanography at coastal scales: Introduction to the special issue on results from the EU FP7 FIELD_AC project, Cont. Shelf Res., 87, 1-6, 2014. 